\title{
Permeable Biosorbent Barrier for Wastewater Remediation
}

\author{
B. Silva ${ }^{1}$ (D) E. Tuuguu ${ }^{2} \cdot$ F. $\operatorname{Costa}^{1} \cdot$ V. Rocha $^{1}$. \\ A. Lago ${ }^{1} \cdot$ T. Tavares ${ }^{1}$
}

Received: 30 November 2016/Accepted: 15 March 2017

(C) Springer International Publishing Switzerland 2017

\begin{abstract}
Chromium is one of the heavy metals that significantly affect water quality in Mongolia. The present study is focused on the remediation of surface water contaminated with chromium (III) by a permeable barrier in order to prevent sediment pollution. The adsorption capacity of the selected materials (13X zeolite and vermiculite) was investigated at different sorbent dosages, $\mathrm{pH}$ and initial $\mathrm{Cr}$ (III) concentration. The equilibrium adsorption studies showed that vermiculite has a higher $\mathrm{Cr}$ (III) removal efficiency in comparison with 13X zeolite. A fungal isolate obtained from the sediment samples collected near Tuul River (Mongolia) was selected from enriched Luria-Bertani medium, showing a good performance for $\mathrm{Cr}$ (III) removal $(78.2 \%$ for an initial concentration of $50 \mathrm{mg} / \mathrm{L}$ ). The fungal isolate was genetically typed by DNA sequencing and was identified as belonging to the Alternaria alternata species. 13X zeolite showed the best performance for $\mathrm{Cr}$ removal in the permeable barrier assays compared to vermiculite, achieving a total removal of $96 \%$ and a global uptake of $2.49 \mathrm{mg} / \mathrm{g}$. After 13 days of operation none of the barriers reached saturation with chromium.
\end{abstract}

Keywords Wastewater $\cdot$ Permeable barrier $\cdot \mathrm{Cr}(\mathrm{III}) \cdot$ Vermiculite $\cdot$ Zeolite $\cdot$ Sediment

\section{Introduction}

Heavy metal contamination in groundwater and sediments is one of the most relevant threats to environmental quality and human health. The presence of heavy metals in

\section{B. Silva}

bsilva@deb.uminho.pt

1 Centre of Biological Engineering, University of Minho, Campus de Gualtar, 4710-057 Braga, Portugal

2 School of Engineering and Applied Sciences, National University of Mongolia, Ulaanbaatar 14201, Mongolia 
the aquatic environment has attracted global attention due to their toxicity, persistence in nature, non-biodegradability and ability to bio-accumulate in food chains. Large quantities of heavy metals have been released into aquatic bodies worldwide due to global rapid population growth and intensive anthropogenic activities (urban, industrial and agricultural sectors). Heavy metals can enter into water systems directly through wastewater discharge or indirectly through rainfall-runoff and atmospheric deposition (Chen et al. 2016). After entering into aquatic systems, heavy metals tend to be adsorbed onto suspended particles and accumulate in sediments. It is often stated that sediments are naturally occurring large sinks and reservoirs for several pollutants such as heavy metals (Salomons and Förstner 1984). These elements adsorbed to sediments may remobilize and be released back to water with a change of environmental conditions, causing secondary pollution and degradation of aquatic systems ( $\mathrm{Li}$ et al. 2001; Zhu et al. 2016). During transport, heavy metals undergo numerous changes in their speciation due to dissolution, precipitation, sorption and complexation phenomena, which influence their behavior and bioavailability (Islam et al. 2015).

Chromium is one of the heavy metals that significantly affects water quality in Mongolia. Among those elements, chromium is one of the most harmful toxic metals and has become a serious health concern. It occurs most frequently as $\mathrm{Cr}(\mathrm{VI})$ or $\mathrm{Cr}(\mathrm{III})$ in aqueous solutions (Silva et al. 2012). In a recent study, Batjargal et al. (2010) reported that the concentration of chromium in 22 soil samples from 11 locations in the capital city Ulaanbaatar ranged between 9.48 and $23.93 \mathrm{mg} / \mathrm{kg}$. The highest concentration of chromium was found in soil samples near a tannery industry.

The conventional remediation technology used to treat contaminated groundwater has been the 'pump and treat' technique, in which the contaminated groundwater is extracted from ground by pumping and then sent to a dedicated water treatment system (Wantanaphong et al. 2005). However, such technique requires continuous energy input and hence is expensive. Thus, in the past three decades, a lot of studies have been conducted towards the development of novel sustainable groundwater remediation techniques (Henderson and Demond 2007). Currently, permeable reactive barriers (PRB) are an effective alternative to conventional remediation technologies for groundwater rehabilitation. A permeable reactive barrier (PRB) involves the emplacement of a reactive media perpendicular to the potential trajectory of the contaminated groundwater, capable of degrading or removing contaminants, transported by water during its natural movement (Vignola et al. 2011; Obiri-Nyarko et al. 2014). The development of this technology has increased rapidly since the first field installation in 1991 (O’Hannesin and Gillham 1998), from lab to full-scale applications.

An important step in constructing PRB is the selection of an effective reactive media. This is generally influenced by the type of pollutants to be removed and by the hydro-geological conditions of the site (Vignola et al. 2011). Zeolites or clays may be used in permeable barriers as low-cost and eco-friendly materials for adsorbing heavy metals from groundwater (Park et al. 2002; Ferronato et al. 2016). Clays are natural scavengers of contaminants by taking up ions either through ion exchange or adsorption or both. Clays have been classified as excellent adsorbent materials due to their remarkable properties such as large specific surface area, chemical and mechanical stability, layered structure and high cation-exchange capacity (CEC) (El-Bayaa et al. 2009). Zeolites are aluminosilicate minerals characterized by cage-like structures, high internal and external surface areas and high cation exchange capacities. Both natural and synthetic zeolites have been used in permeable barriers to remove metals from groundwater (Park et al. 2002; Statham et al. 2016). The current study (Silva et al. 2016) is 
focused on the remediation of water with $\mathrm{Cr}$ (III) to prevent sediment pollution using zeolite and vermiculite in a lab-scale reactor, simulating a permeable barrier.

In recent years, the use of microorganisms in bioremediation purposes has become popular since it foresees sustainable technologies to re-establish the natural conditions of water, soil and sediments. In metal polluted environments, microorganisms have the ability to adapt to toxic concentrations of those elements and become metal resistant, developing strategies to resist, tolerate, metabolize and detoxify those metals (Parsek et al. 1995). In this work, the isolation and identification of heavy metal resistant fungi present in sediment samples collected from the margins of Tuul River (Mongolia) was performed in order to assess their applicability to chromium removal.

\section{Experimental}

\subsection{Characterization Procedures}

\subsubsection{Sediment Characterization}

Surface sediment samples (MSed) were collected from Tuul River margins (Ulaanbaatar, Mongolia) in a polluted area near the central wastewater treatment plant. The elemental analyses of samples was performed by ICP-OES (Optima 8000, Perkin-Elmer), after microwave digestion (MDS 2000, CEM) with nitric acid using US EPA method 3051A (USEPA 2007).

The enrichment factor (EF) was used to assess the degree of heavy metal contamination in the collected surface sediments. The EF for each element was calculated in order to evaluate the anthropogenic influence on the heavy metal content in sediments. For comparison purposes, the average upper continental crust (UCC) values (Rudnick and Gao 2003) were used as reference in the following formula:

$$
E F=\frac{\left(C_{m} / C_{A l}\right)_{\text {sample }}}{\left(C_{m} / C_{A l}\right)_{U C C}}
$$

where $C_{\mathrm{m}}$ and $C_{\mathrm{Al}}$ represent respectively the concentrations of metal $m$ and of aluminum in the samples and in UCC. Al was used as the reference element for geochemical normalization since it represents the aluminosilicates which are generally the predominant carrier phase for metals in coastal sediments and its natural concentration tends to be uniform (Alexander et al. 1993).

\subsubsection{Determination of Point of Zero Charge (pHpzc)}

Synthetic 13X zeolite and vermiculite were used as adsorbent materials in this work. The zeolite $13 \mathrm{X}$ was supplied in the form of pellets $(5-8 \mathrm{~mm})$ by Xiamen Zhongzhao Imp. \& Exp. Co. The natural clay vermiculite $(2-3 \mathrm{~mm})$ was purchased from SigmaAldrich. The pHpzc values of each adsorbent material was measured by preparing a solution of $0.01 \mathrm{M} \mathrm{NaCl}$, previously bubbled with nitrogen in order to stabilize the $\mathrm{pH}$ by preventing the dissolution of $\mathrm{CO}_{2}$. The $\mathrm{pH}$ was adjusted to different values 
between 1 and 9 by adding diluted $\mathrm{H}_{2} \mathrm{SO}_{4}$ or $\mathrm{NaOH}$. For each $\mathrm{pH}$ value, the adsorbent $(0.10 \mathrm{~g})$ was added to $25 \mathrm{~mL}$ of $\mathrm{NaCl}$ solution in conical flasks of $50 \mathrm{~mL}$. All the flasks were sealed to avoid contact with air and left under moderate agitation at room temperature for $48 \mathrm{~h}$. The samples were then filtered and the final $\mathrm{pH}$ of filtrate was measured and plotted against the initial $\mathrm{pH}$. The $\mathrm{pH}$ at which the curve crossed the line $\mathrm{pH}_{\text {initial }}=\mathrm{pH}_{\text {final }}$ was taken as the point of zero charge (pHpzc).

\subsection{Batch Adsorption Assays}

The adsorption capacity of $13 \mathrm{X}$ zeolite and of vermiculite was investigated at different adsorbent doses $(0.1,0.5,1.0$ and $2.0 \mathrm{~g})$. The adsorption experiments were carried out in batch system, in $100 \mathrm{~mL}$ stoppered Erlenmeyer flasks containing $25 \mathrm{~mL}$ of $\mathrm{Cr}(\mathrm{III})$ solution with initial concentration of $10 \mathrm{mg} / \mathrm{L}$. The solution $\mathrm{pH}$ was regularly adjusted to 4. The Erlenmeyer flasks were kept at $27{ }^{\circ} \mathrm{C}$ for $24 \mathrm{~h}$, with moderate stirring $(100 \mathrm{rpm})$. At the end, the content of the flasks was centrifuged and filtered, being the filtrate analyzed for chromium concentration by ICP-OES (Optima 8000, Perkin-Elmer). The uptake, amount of metal adsorbed per unit mass of adsorbent, $\mathrm{q}_{\mathrm{e}}$ $(\mathrm{mg} / \mathrm{g})$, and the percentage removal, R $(\%)$ were calculated as follows:

$$
\begin{gathered}
q_{e}=\frac{\left(C_{i}-C_{f}\right) \times V}{m} \\
R=\frac{\left(C_{i}-C_{f}\right) \times 100}{C_{i}}
\end{gathered}
$$

where $C_{\mathrm{i}}$ and $\mathrm{C}_{\mathrm{f}}$ are, respectively, the initial and the final $\mathrm{Cr}(\mathrm{III})$ concentrations $(\mathrm{mg} / \mathrm{L}), m$ is the mass of adsorbent ( $\mathrm{g}$ ) and $V$ the volume of solution (L).

\subsection{Microorganism Isolation and Molecular Identification}

A sediment sample (MSed) from Tuul River margins (Ulaanbaatar, Mongolia) was aseptically collected and spread directly in a Dichloran Rose Bengal Chlortetracycline (DRBC) agar medium and maintained in the dark, at $37^{\circ} \mathrm{C}$ for 5 days. The colonies formed were aseptically collected and successively subcultured in sterilized DRBC agar medium. This procedure was repeated tenfold in order to ensure the isolation of the culture. Then the isolates were inoculated in an enriched modified Luria-Bertani (LB) medium (10 g/L typtone, $5 \mathrm{~g} / \mathrm{L} \mathrm{NaCl}$ and $5 \mathrm{~g} / \mathrm{L}$ yeast extract). From 3 initial fungal isolates, one was selected on the basis of its morphology and growth rate.

The selected fungal isolate was inoculated separately into a new fresh Malt Extract Agar (MEA) liquid medium and maintained at $25^{\circ} \mathrm{C}, 150 \mathrm{rpm}$ for $24 \mathrm{~h}$. DNA extraction was performed according to PowerSoil@DNA Isolation Kit, MO Bio Laboratories, Inc.

DNA extract was used to amplify the Internal Transcribe Sequences (ITS) surrounding the 5.8S-coding sequence, situated between the Small SubUnit-coding sequence (SSU) and the Large SubUnit-coding sequence (LSU) of the ribosomal operon. 
The ITS region was amplified by PCR using fungal primers ITS4 5'-TCCT CCGCTTATTGATATGC-3' and ITS1-F 5'-CTTGGTCATTTAGAGGAAGTAA-3'. Amplifications were carried out in a Bio-Rad MYCYCLER thermal cycler using a temperature gradient protocol.

PCR amplification products were analyzed by electrophoresis. The sequencing of the PCR products were conducted by Macrogen Europe (Meibergdreef, Amsterdam, Netherland) and subjected to a GenBank BLAST in the National Center for Biotechnology Information (NCBI database) search to retrieve sequences of closely related taxa.

\subsection{Kinetics of Cellular Growth and Chromium Removal by the Fungal Isolate}

Metal sorption experiments were performed in order to assess the effect of $\mathrm{Cr}$ (III) on the cellular growth of the fungal isolate and to evaluate its ability to remove chromium, the selected fungal isolate was inoculated into $250-\mathrm{mL}$ flasks containing enriched modified LB medium. The medium was supplemented with chromium at two different initial concentrations $(50 \mathrm{mg} / \mathrm{L}$ and $100 \mathrm{mg} / \mathrm{L})$. A control without chromium was maintained to assess the normal growth of the isolate. The flasks were mixed in a rotary shaker $(150 \mathrm{rpm})$ at $27{ }^{\circ} \mathrm{C}$ for $50 \mathrm{~h}$. Samples were collected at regular intervals and the cell growth was monitored by measuring the optical density at $600 \mathrm{~nm}$. The samples were then centrifuged and the supernatant was analyzed for chromium concentration by ICP-OES (Optima 8000, Perkin-Elmer). The maximum specific growth rate of the cells was determined from the exponential phase of each assay.

\subsection{Permeable Barrier Reactor Studies}

A lab-scale permeable barrier reactor (PBR) was designed, consisting of a horizontal Plexiglas column (40 cm length, $15 \mathrm{~cm} \varnothing$ ) with a barrier made of adsorbent material with $5 \mathrm{~cm}$ width, as presented in Fig. 1. Two adsorbent materials were tested as barriers for $\mathrm{Cr}(\mathrm{III})$ removal: vermiculite and $13 \mathrm{X}$ zeolite.

A synthetic $50 \mathrm{mg} / \mathrm{L} \mathrm{Cr}$ (III) solution was fed to the reactor with a flow rate of $2 \mathrm{~mL} / \mathrm{min}$, using a laboratory peristaltic pump (Masterflex, Cole-Parmer), until a steady-state concentration profile was achieved. The outlet chromium concentration was regularly measured by ICPOES (Optima 8000, Perkin-Elmer). This procedure was performed two times, one with a barrier made of vermiculite $(221 \mathrm{~g})$ and another with a barrier made of 13X zeolite (1078 $\mathrm{g})$.

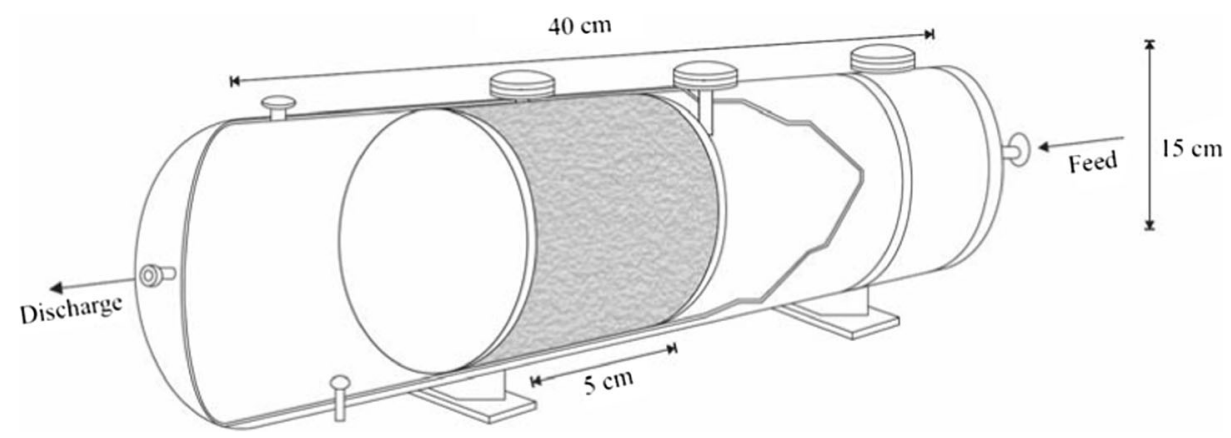

Fig. 1 Permeable barrier reactor design 


\section{Results}

\subsection{Characterization of Sediment}

The heavy metals contents found in sediment collected from Tuul River (MSed) are presented in Table 1. The average upper-crustal composition (UCC) and the calculated enrichment factors (EF) are also given in Table 1.

In this work, EF values were interpreted as the levels of metal pollution as suggested by Acevedo-Figueroa et al. (2006), where $\mathrm{EF}<1$ indicates no enrichment, $<3$ is minor enrichment, $3-5$ is moderate enrichment, 5-10 is moderately severe enrichment, $10-25$ is severe enrichment, $25-50$ is very severe enrichment, and $>50$ is extremely severe enrichment. The maximum values of $\mathrm{EF}$ were obtained for $\mathrm{Zn}$ and $\mathrm{Pb}$ which indicate a very severe enrichment of these metals. On its turn, the EF value found for $\mathrm{Cr}$ indicates severe enrichment, whereas $\mathrm{Cu}$ showed moderately severe enrichment and Fe demonstrated moderate enrichment. According to Zhang and Liu (2002), EF values higher than 1.5 suggest that a significant portion of metal is delivered from non-crustal materials and probably the sources are anthropogenic. The obtained $\mathrm{EF}$ values indicated that metal contamination (with $\mathrm{Cu}, \mathrm{Zn}, \mathrm{Pb}, \mathrm{Cr}$ and $\mathrm{Fe}$ ) occurred in the sediment collected from the Tuul River.

\subsection{Point of Zero Charge (pHzpc)}

The $\mathrm{pH}$ of zero point of charge ( $\mathrm{pHzpc}$ ) corresponds to the $\mathrm{pH}$ value at which the net surface charge of the adsorbent becomes electrically neutral. It plays an important role during the sorption of ionic species on solid surfaces from aqueous systems. At $\mathrm{pH}<\mathrm{pHzpc}$, the adsorbent surface becomes positively charged, which favors the sorption of anionic species, while at $\mathrm{pH}>\mathrm{pHzpc}$, the adsorbent surface is negatively charged which is favorable for sorption of cationic species.

The experimental results of $\mathrm{pHzpc}$ determination, using the $\mathrm{pH}$ drift method, are shown in Fig. 2.

The $\mathrm{pHzpc}$ value obtained for both adsorbent materials was 8.8 , that is the $\mathrm{pH}$ at which the curve crosses the line $\mathrm{pH}_{\text {initial }}=\mathrm{pH}_{\text {final }}$. This value of $\mathrm{pHzpc}$ indicates that above the $\mathrm{pH}$ of 8.8 , both adsorbent surfaces become negatively charged which helps the electrostatic binding of positively charged $\mathrm{Cr}^{3+}$ ions. As it can be observed in Fig. 2, both vermiculite and $13 \mathrm{X}$ zeolite surfaces exhibit amphoteric properties, acting as a buffer in a wide $\mathrm{pH}$ range of 4 to 9 , where the final $\mathrm{pH}$ remains almost close to the $\mathrm{pHzpc}$ for all values of initial $\mathrm{pH}$ in this range.

Table 1 Content of heavy metals in sediment collected from Tuul River ( $\mathrm{mg} / \mathrm{kg}$ ), upper-crustal composition (UCC) and calculated EF values

\begin{tabular}{lllllll}
\hline & $\mathrm{Cu}$ & $\mathrm{Zn}$ & $\mathrm{Pb}$ & $\mathrm{Cr}$ & $\mathrm{Al}$ & $\mathrm{Fe}^{*}$ \\
\hline MSed & 22.4 & 176 & 40.6 & 152 & 1.43 & 1.77 \\
UCC & 28.0 & 67.0 & 17.0 & 92.0 & 15.4 & 5.04 \\
EF & 8.62 & 28.3 & 25.7 & 17.8 & - & 3.78 \\
\hline
\end{tabular}

*values in \% 
Fig. 2 Determination of pHzpc values of vermiculite and $13 \mathrm{X}$ zeolite using the $\mathrm{pH}$ drift method

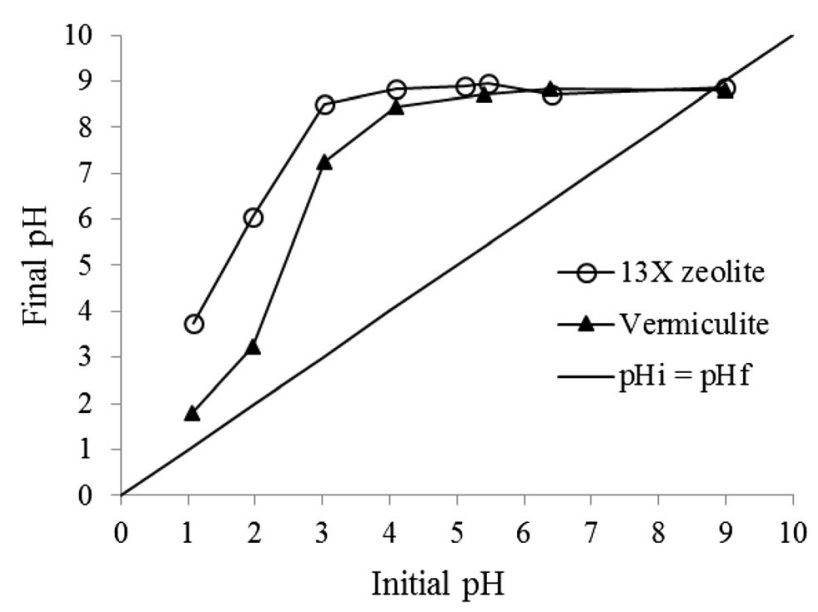

\subsection{Adsorption Studies}

To evaluate the effect of the amount of adsorbent (vermiculite and $13 \mathrm{X}$ zeolite) on the adsorption capacity of $\mathrm{Cr}(\mathrm{III})$, equilibrium experiments were performed at different adsorbent dosages, ranging from $0.1 \mathrm{~g}$ to $2.0 \mathrm{~g}$. The results are shown in Fig. 3a and b, for 13X zeolite and vermiculite, respectively.

As shown in Fig. 3a, the removal efficiency of chromium increased (from $8 \%$ to $71 \%$ ) as the dosage of zeolite increased from 0.1 to $2.0 \mathrm{~g}$. This may be explained by the increase of absolute number of available active sites of the zeolite, thus facilitating the binding of chromium ions. For vermiculite, the chromium removal was maximized and was independent from the adsorbent dosage in the range $0.1-2.0 \mathrm{~g}$.

As it can be observed in Fig. 3a and b, the increase of adsorbent dose led to the decrease of adsorption capacity ( $\mathrm{q}_{\mathrm{e}}$, amount adsorbed per unit mass), for both adsorbents, and this is mainly due to adsorption sites that remain unsaturated during the adsorption process, whereas the number of sites available for adsorption increases with the adsorbent dose (Yener et al. 2006).

As seen in Fig. $3 \mathrm{a}$ and $\mathrm{b}$, the maximum adsorption capacity reached $0.20 \mathrm{mg} / \mathrm{g}$ using $0.1 \mathrm{~g}$ of $13 \mathrm{X}$ zeolite, and $2.48 \mathrm{mg} / \mathrm{g}$ using $0.1 \mathrm{~g}$ of vermiculite. Regarding the pHzpc obtained for both adsorbents, at $\mathrm{pH} 8.8$, it is expected that the adsorption capacity would be greatly enhanced if the $\mathrm{pH}$ of the synthetic solution of $\mathrm{Cr}(\mathrm{III})$ was adjusted to a value above the pHzpc. However, at higher $\mathrm{pH}$ values, $\mathrm{OH}^{-}$ions form hydroxyl complexes with $\mathrm{Cr}, \mathrm{Cr}(\mathrm{OH})_{3}$. For the initial $\mathrm{Cr}$ concentration used, $10 \mathrm{mg} / \mathrm{L}$, it is predictable that $\mathrm{Cr}(\mathrm{OH})_{3}$ starts to precipitate at $\mathrm{pH}$ values higher than 5.19 (solubility product constant, Ksp $\left.\left[\mathrm{Cr}(\mathrm{OH})_{3}\right]=6.70 \times 10^{-31}\right)$. Therefore, in order to prevent precipitation, the initial $\mathrm{pH}$ of $\mathrm{Cr}$ (III) solution used in the adsorption assays was not previously adjusted.

\subsection{Cellular Growth and Cr Removal by the Fungal Isolate}

The results of molecular identification revealed that the fungi isolated from the sediment collected from Tuul River was identified as belonging to the Alternaria alternata species $(95 \%$ similarity, accession number KT192386.1). 

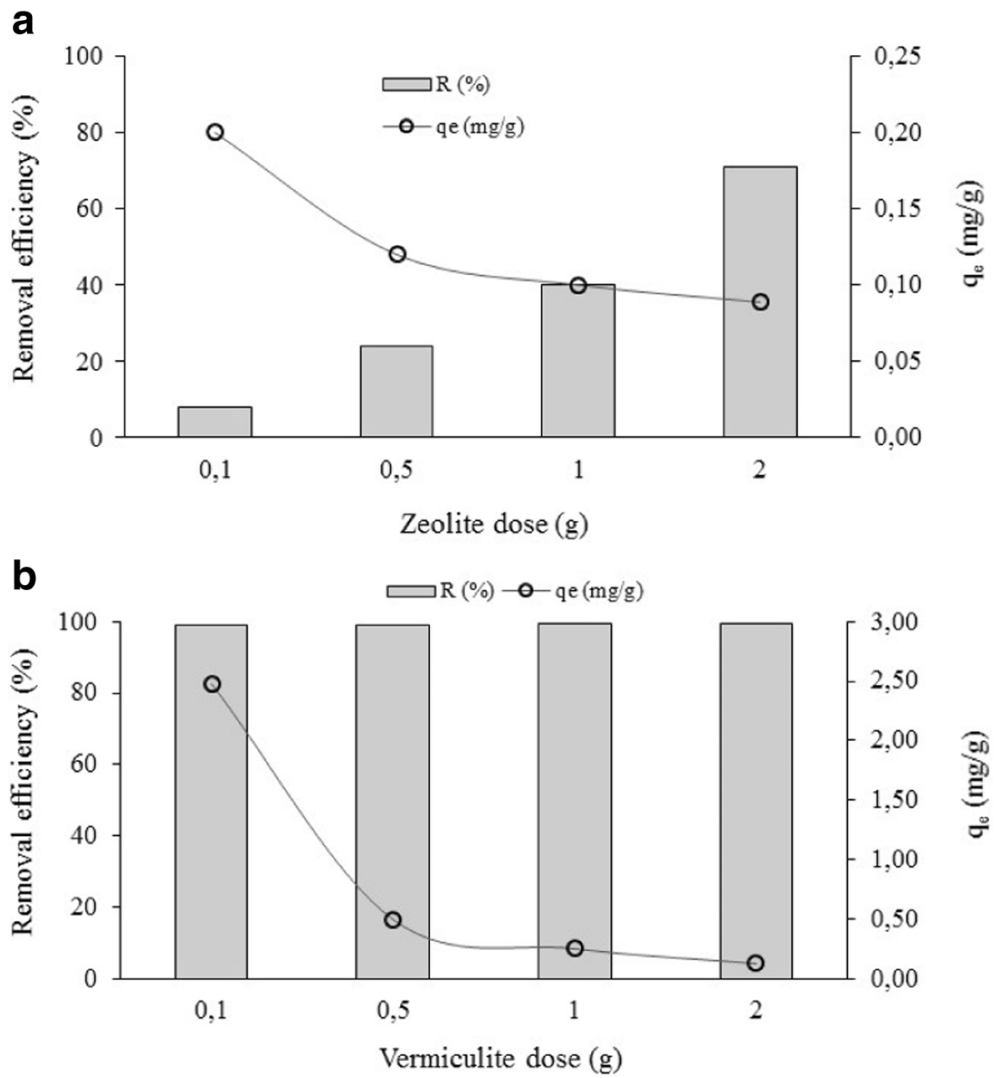

Fig. 3 The effect of adsorbent dose on Cr(III) removal efficiency and uptake: (a) 13X zeolite, (b) vermiculite

In order to evaluate the removal of chromium by the fungal isolate and to access its influence on cellular growth behavior, sorption assays were performed. The growth curves and the maximum specific growth rates for the fungal isolate in the absence and in the presence of $\mathrm{Cr}$ (III) are presented in Fig. 4.

As it can be observed, the maximum specific growth rate of Alternaria alternata was higher for the control (0 $\mathrm{mg} / \mathrm{L}$ of chromium), decreasing when the initial

Fig. 4 Growth curves and maximum specific growth rates for Alternaria alternata in the absence and in the presence of $\mathrm{Cr}$ (III) $(50 \mathrm{mg} / \mathrm{L}$ and $100 \mathrm{mg} / \mathrm{L})$

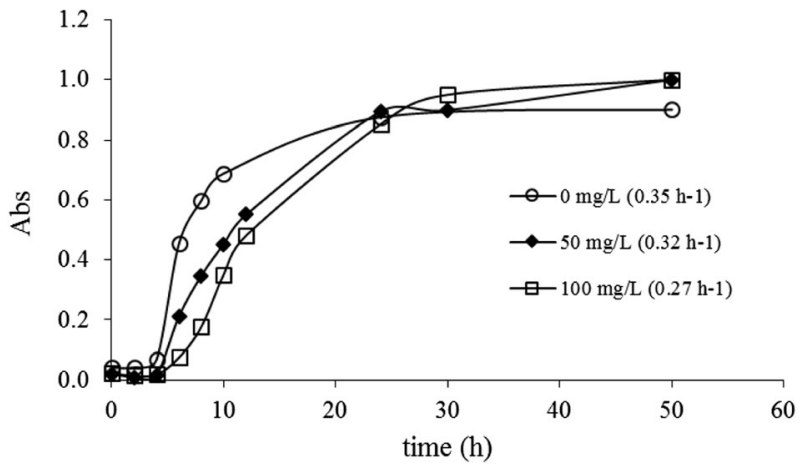


a

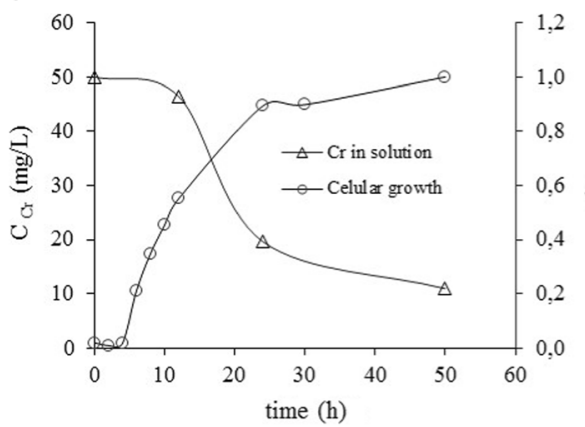

b

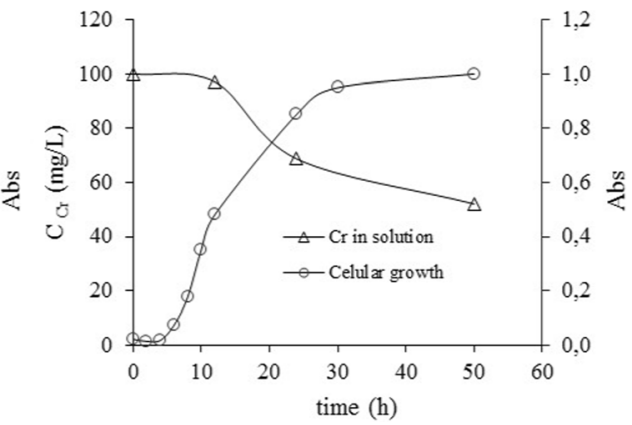

Fig. 5 Growth curves of Alternaria alternata and chromium concentration profiles in solution, for a starting concentration of $\mathrm{Cr}(\mathrm{III})$ of $50 \mathrm{mg} / \mathrm{L}$ (a) and $100 \mathrm{mg} / \mathrm{L}$ (b)

concentration of $\mathrm{Cr}$ increased. The maximum decrease in the specific growth rate, $22.9 \%$, was attained in the presence of the highest concentration of chromium, $100 \mathrm{mg} / \mathrm{L}$.

The time-course data for chromium removal and cellular growth were observed for Alternaria alternata for each initial metal concentration, as presented in Fig. 5a and b. The results show that chromium starts to be removed from solution when cells reach the exponential growth phase. However, the removal rate of $\mathrm{Cr}$ (III) sharply decreased during the stationary phase of growth. This trend was observed for both initial concentrations. After $50 \mathrm{~h}$ of cellular growth the fungal isolate was able to remove $78.2 \%$ and $47.9 \%$ of $\mathrm{Cr}$ (III) at the initial concentration of $50 \mathrm{mg} / \mathrm{L}$ and $100 \mathrm{mg} / \mathrm{L}$, respectively.

\subsection{Permeable Barrier Reactor}

Figure 6 compares the performance of two adsorbent materials, vermiculite and $13 \mathrm{X}$ zeolite, during the permeable barrier reactor assays. The inlet chromium concentration

Fig. 6 Chromium concentration profiles during continuous operation of PBR reactor, using a barrier of vermiculite and a barrier of $13 \mathrm{X}$ zeolite

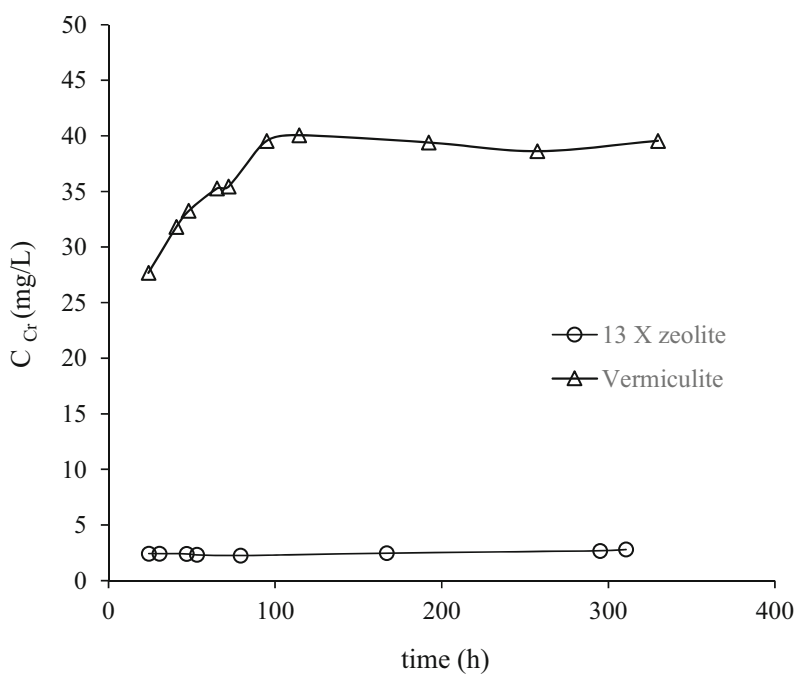


Table 2 Experimental details, global uptake and removal achieved during the permeable barrier reactor studies

\begin{tabular}{lllllll}
\hline Experiment & Barrier & $\begin{array}{l}\text { Mass of } \\
\text { adsorbent }(\mathrm{g})\end{array}$ & $\begin{array}{l}\text { Inlet } \mathrm{pH} \\
(\text { range })\end{array}$ & $\begin{array}{l}\text { Outlet pH } \\
\text { (range) }\end{array}$ & $\begin{array}{l}\text { Global removal } \\
(\%)\end{array}$ & $\begin{array}{l}\text { Global uptake } \\
(\mathrm{mg} / \mathrm{g})\end{array}$ \\
\hline $\mathrm{A}$ & Vermiculite & 221 & $3.58-3.71$ & $4.05-4.50$ & 30.9 & $3.38^{\mathrm{a}}$ \\
$\mathrm{B}$ & $13 \mathrm{X}$ zeolite & 1078 & & $9.93-10.2$ & 96.0 & $2.49^{\mathrm{b}}$ \\
\hline
\end{tabular}

${ }^{\text {a }}$ Total mass of $\mathrm{Cr}$ adsorbed on vermiculite, per unit mass of adsorbent

${ }^{\mathrm{b}}$ Total mass of $\mathrm{Cr}$ retained (adsorbed/precipitated) by zeolite barrier, per unit mass of adsorbent

was set on $50 \mathrm{mg} / \mathrm{L}$ for both experiments. The global uptake achieved by each adsorbent material and other experimental details are given in Table 2. A noticeable difference between the performances of vermiculite and $13 \mathrm{X}$ zeolite was observed. During the experiment with a barrier made of vermiculite, the concentration of chromium in the outlet stream increased from $28 \mathrm{mg} / \mathrm{L}$ to $40 \mathrm{mg} / \mathrm{L}$ during the first 4 days of operation $(96 \mathrm{~h}$ ), remaining constant until the end of the assay. After 14 days of operation the vermiculite-barrier was not saturated with chromium, achieving a global uptake of $3.38 \mathrm{mg} / \mathrm{g}$ and an overall removal of $30.9 \%$. Regarding the experiment with $13 \mathrm{X}$ zeolite, the concentration of $\mathrm{Cr}$ in the outlet stream was almost constant, during the 13 days of experiment, ranging between $2.4 \mathrm{mg} / \mathrm{L}$ and $2.8 \mathrm{mg} / \mathrm{L}$. Therefore, 13X zeolite exhibited an excellent performance for $\mathrm{Cr}$ removal, achieving a total removal of $96 \%$ and a global uptake of $2.49 \mathrm{mg} / \mathrm{g}$. As can be seen from Table 2, the barrier made of $13 \mathrm{X}$ zeolite increased the solution $\mathrm{pH}$ up to 10.2 which led to the precipitation of $\mathrm{Cr}$. For this reason, the retention of $\mathrm{Cr}$ in the barrier was performed either by adsorption or precipitation processes. For the experiment with a barrier of vermiculite, the solution $\mathrm{pH}$ did not change significantly, so the removal of $\mathrm{Cr}$ was performed exclusively by adsorption.

\section{Conclusions}

The sediment collected from Tuul River margins revealed a significant enrichment in heavy metals such as $\mathrm{Pb}, \mathrm{Zn}$ and $\mathrm{Cr}$, when compared with average upper continental crust values, suggesting anthropogenic inputs probably linked to leather processing activities.

The batch adsorption studies revealed that for the adsorbent dosage ranging from $0.1 \mathrm{~g}$ to $2.0 \mathrm{~g}$, vermiculite had a better performance in $\mathrm{Cr}(\mathrm{III})$ removal in comparison with $13 \mathrm{X}$ zeolite.

The fungi isolated from the sediment collected from Tuul River, identified as belonging to the Alternaria alternata species, showed a good performance in $\mathrm{Cr}(\mathrm{III})$ removal.

13X zeolite showed the best performance in $\mathrm{Cr}$ removal in the permeable barrier reactor tests. While the removal of $\mathrm{Cr}$ by the barrier of vermiculite was performed exclusively by adsorption, for $13 \mathrm{X}$ zeolite chromium was removed by a coupled adsorption/precipitation process. After 13 days of operation none of the barriers reached the saturation with chromium.

Acknowledgements A previous version of the paper has been presented in the 2nd EWaS International Conference: "Efficient \& Sustainable Water Systems Management toward Worth Living Development", Chania, Crete, Greece, 1-4 June 2016. This study was supported by the Portuguese Foundation for Science and Technology (FCT) under the scope of the strategic funding of UID/BIO/04469/2013 unit and COMPETE 2020 (POCI-01-0145-FEDER-006684) and BioTecNorte operation (NORTE-01-0145-FEDER-000004) funded 
by the European Regional Development Fund under the scope of Norte2020 - Programa Operacional Regional do Norte. Bruna Silva is thankful to the FCT for the concession of a Post-Doc grant (SFRH/BPD/112354/2015). Sampling process was supported by the collaborative research grant of National Academy of Sciences of Taiwan and Science and Technology Foundation of Mongolia, project code NCS-NECS2013003 and co-funded by the Young Scientist Grant (SEAS-2015075) of National University of Mongolia. E. Tuuguu would like to acknowledge the Erasmus-Mundus AREAS+ program for the opportunity to conduct research at CEB-University of Minho.

\section{Compliance with Ethical Standards}

Conflict of Interest The authors declare that they have no conflict of interest.

\section{References}

Acevedo-Figueroa D, Jiménez BD, Rodríguez-Sierra CJ (2006) Trace metals in sediments of two estuarine lagoons from Puerto Rico. Environ Pollut 141:336-342. doi:10.1016/j.envpol.2005.08.037

Alexander CR, Smith RG, Calder FD, Schropp SJ, Windom HL (1993) The historical record of metal enrichment in two Florida estuaries. Estuaries 16:627-637. doi:10.2307/1352800

Batjargal T, Otgonjargal E, Baek K, Yang J-S (2010) Assessment of metals contamination of soils in Ulaanbaatar, Mongolia. J Hazard Mater 184:872-876. doi:10.1016/j.jhazmat.2010.08.106

Chen C-F, Ju Y-R, Chen C-W, Dong C-D (2016) Vertical profile, contamination assessment, and source apportionment of heavy metals in sediment cores of Kaohsiung Harbor, Taiwan. Chemosphere 165:6779. doi:10.1016/j.chemosphere.2016.09.019

El-Bayaa AA, Badawy NA, AlKhalik EA (2009) Effect of ionic strength on the adsorption of copper and chromium ions by vermiculite pure clay mineral. J Hazard Mater 170:1204-1209. doi:10.1016/j. jhazmat.2009.05.100

Ferronato C, Silva B, Costa F, Tavares T (2016) Vermiculite bio-barriers for $\mathrm{Cu}$ and $\mathrm{Zn}$ remediation: an ecofriendly approach for freshwater and sediments protection. Int J Environ Sci Technol 13:1219-1228. doi:10.1007/s13762-016-0957-8

Henderson AD, Demond AH (2007) Long-term performance of zero-valent iron permeable reactive barriers: a critical review. Environ Eng Sci 24:401-423. doi:10.1089/ees.2006.0071

Islam MS, Ahmed MK, Raknuzzaman M et al (2015) Heavy metal pollution in surface water and sediment: A preliminary assessment of an urban river in a developing country. Ecol Indic 48:282-291. doi:10.1016/j. ecolind.2014.08.016

Li X, Shen Z, Wai OWH, Li Y-S (2001) Chemical forms of Pb, $\mathrm{Zn}$ and $\mathrm{Cu}$ in the sediment profiles of the Pearl River Estuary. Mar Pollut Bull 42:215-223. doi:10.1016/S0025-326X(00)00145-4

O'Hannesin SF, Gillham RW (1998) Long-term performance of an in situ "iron wall" for remediation of VOCs. Ground Water 36:164-170

Obiri-Nyarko F, Grajales-Mesa SJ, Malina G (2014) An overview of permeable reactive barriers for in situ sustainable groundwater remediation. Chemosphere 111:243-259. doi:10.1016/j.chemosphere.2014.03.112

Park J-B, Lee S-H, Lee J-W, Lee C-Y (2002) Lab scale experiments for permeable reactive barriers against contaminated groundwater with ammonium and heavy metals using clinoptilolite (01-29B). J Hazard Mater 95:65-79. doi:10.1016/S0304-3894(02)00007-9

Parsek MR, McFall SM, Chakrabarty AM (1995) Microbial degradation of toxic, environmental pollutants: Ecological and evolutionary considerations. Int Biodeterior Biodegrad 35:175-188. doi:10.1016/0964-8305(95)00032-Z

Rudnick RL, Gao S (2003) 3.01 - Composition of the Continental Crust A2 - Holland, Heinrich D. In: Turekian KKBT-T on G (ed). Pergamon, Oxford, pp 1-64

Salomons W, Förstner U (1984) Sediments and the Transport of Metals. In: Metals in the Hydrocycle. Springer, Berlin, pp 63-98

Silva B, Figueiredo H, Quintelas C, Neves IC, Tavares MT (2012) Improved biosorption for Cr(VI) reduction and removal by Arthrobacter viscosus using zeolite. Int Biodeterior Biodegrad 74:116-123. doi: 10.1016/j. ibiod.2012.05.026

Silva B, Tuuguu E, Costa F et al (2016) Permeable biosorbent barrier for wastewater remediation. In: 2nd EWaS International Conference: "Efficient \& Sustainable Water Systems Management toward Worth Living Development, 1-4 June 2016. Chania, Crete, Greece 
Statham TM, Stark SC, Snape I, Stevens GW, Mumford KA (2016) A permeable reactive barrier (PRB) media sequence for the remediation of heavy metal and hydrocarbon contaminated water: a field assessment at Casey Station, Antarctica. Chemosphere 147:368-375. doi:10.1016/j.chemosphere.2015.12.133

USEPA (2007) Microwave assisted acid digestion of sediments, sludges, soils, and oils, 3051. Environmental Protection Agency, United States of America

Vignola R, Bagatin R, De Folly D'AA et al (2011) Zeolites in a permeable reactive barrier (PRB): one year of field experience in a refinery groundwater-Part 1: The performances. Chem Eng J 178:204-209. doi:10.1016/j.cej.2011.10.050

Wantanaphong J, Mooney SJ, Bailey EH (2005) Natural and waste materials as metal sorbents in permeable reactive barriers (PRBs). Environ Chem Lett 3:19-23. doi:10.1007/s10311-005-0106-y

Yener J, Kopac T, Dogu G, Dogu T (2006) Adsorption of basic yellow 28 from aqueous solutions with clinoptilolite and amberlite. J Colloid Interface Sci 294:255-264. doi:10.1016/j.jcis.2005.07.040

Zhang J, Liu CL (2002) Riverine composition and estuarine geochemistry of particulate metals in Chinaweathering features, anthropogenic impact and chemical fluxes. Estuar Coast Shelf Sci 54:1051-1070. doi:10.1006/ecss.2001.0879

Zhu X, Shan B, Tang W (2016) Heavy metal in sediments of Ziya River in northern China: distribution, potential risks, and source apportionment. Environ Sci Pollut Res:1-11. doi:10.1007/s11356-016-7561-9 